\title{
PENGEMBANGAN LEMBAR KERJA SISWA MODEL INKUIRI TERBIMBING MATERI ELEKTROKIMIA KELAS XII SMA
}

\author{
Eka Tina Nur Ula Tuqa ${ }^{1)}$, Suyono $^{2)}$, Bambang Sugiarto ${ }^{3)}$ \\ 1) Mahasiswa Program Studi S2 Pendidikan Sains, Universitas Negeri Surabaya \\ 2) Dosen Program Studi S2 Pendidikan Sains, Universitas Negeri Surabaya \\ ${ }^{3)}$ Dosen Program Studi S2 Pendidikan Sains, Universitas Negeri Surabaya \\ Email: blueivanotsky@yahoo.co.id
}

\begin{abstract}
Abstrak: Tujuan penelitian ini adalah dihasilkannya Lembar Kerja Siswa (LKS) yang valid, praktis, dan efektif untuk mendukung pembelajaran materi elektrokimia menggunakan model inkuiri terbimbing. Pengembangan LKS menggunakan model ADDIE (analyze, design, develop, implement, dan evaluate) dan diterapkan di kelas XII SMA Trensains Tebuireng, Jombang semester gasal tahun ajaran 2016/2017 dengan menggunakan One-Group PretestPosttest Design. Validitas LKS diukur dari aspek relevansi (validitas isi) dan aspek konsistensi (validitas konstruk) berdasarkan penilaian expert dengan skor minimal 2,60 (Valid). Kepraktisan LKS diukur dari aktivitas siswa yang dinyatakan baik dengan persentase minimal 60\%. Efektivitas LKS diukur berdasarkan pengaruhnya terhadap kenaikan hasil belajar siswa pada aspek pengetahuan pada pilot implementation maupun final implementation. Data validitas dan kepraktisan LKS dianalisis secara deskriptif kuantitatif sedangkan data efektivitas LKS dianalisis secara inferensial menggunakan uji-t. Berdasarkan analisis data diperoleh hasil bahwa: (1) validitas isi dan validitas konstruk LKS berada pada kategori rata-rata sangat valid; (2) aktivitas siswa berada pada kategori rata-rata sangat baik; (3) skor rata-rata hasil belajar siswa meningkat secara signifikan daripada kemampuan awal siswa.
\end{abstract}

Kata Kunci: lembar kerja siswa, inkuiri terbimbing, elektrokimia

\begin{abstract}
This research aimed to develop valid, practical, and effective worksheet to support electrochemistry learning using guided inquiry model. Development of worksheet based on ADDIE model (Analyse, Design, Develop, Implement, and Evaluate). Worksheet were implemented at grade XII chemistry students using one group pretestposttest design. Validity of worksheet was measured from relevance and consistency based on expert judgment with minimum score of 2,6. Practicality of worksheet was measured from students activity with minimun percentage of $60 \%$. Effectivenes of worksheet was measured from its impact to increase student's cognitive achievement significanly. Validity and practicality was analyzed using descriptive statistics, whereas effectiveness of cognitive achievement was analyzed using inferential t-test. The result of data analysis were: (1) content validiy and construct validity of worksheet developed was very valid; (2) students activity were very good; (3) cognitive achievement has increased significanly both in pilot implementation and final implementation.
\end{abstract}

Keywords: worksheet, guided inquiry, electrochemistry

\section{PENDAHULUAN}

Ilmu Kimia merupakan cabang dari Ilmu Pengetahuan Alam yang mempelajari struktur materi, reaksi kimia, dan energi yang menyertai perubahan tersebut (Poulson, 2010). Pengetahuan tentang kimia diperoleh melalui buah pemikiran dan penyelidikan ilmuwan yang dilakukan dengan keterampilan bereksperimen menggunakan metode ilmiah. Pembelajaran kimia yang efektif harus memberi kesempatan bagi siswa untuk melakukan kegiatan eksperimen agar membentuk pengetahuan konseptual yang utuh dalam pemahamannya sehingga pengetahuan tidak hanya dihafal semata (Milliar et al., 1998).
Model pembelajaran inkuiri sesuai dengan pendekatan ilmiah, di mana siswa belajar melalui berbagai kegiatan termasuk melakukan observasi, mengajukan pertanyaan, mencari dan menggali informasi melalui eksperimen, memanipulasi alat dan bahan, menafsirkan data, mengajukan pertanyaan, memprediksi, dan mengomunikasikan hasil (Ong \& Borich, 2006). Pembelajaran inkuiri memiliki berbagai tingkatan sesuai kompleksitasnya, di antaranya adalah inkuiri terbimbing di mana tema permasalahan diajukan oleh guru namun pengajuan solusi dan diskusi hasil dilakukan oleh siswa. Model inkuiri terbimbing digunakan dalam pembelajaran ketika para siswa belum terbiasa menggunakan inkuiri secara penuh. 
Kegiatan inkuiri terbimbing dalam pembelajaran dapat meningkatkan berpikir tingkat tinggi siswa. Para siswa diharuskan menciptakan pengetahuan untuk diri sendiri melalui proses pengumpulan dan analisis data, mengevaluasi data, dan mengomunikasikan hasil dalam diskusi. McDonnel et al. (2013) menggunakan taksonomi Bloom untuk mendefinisikan kemampuan berpikir tingkat tinggi dalam penelitiannya, yaitu analisis (C4), evaluasi (C5), dan kreasi (C6). Miri et al (2007) menunjukkan bahwa terdapat beberapa strategi dalam pembelajaran inkuiri terbimbing yang menyebabkan meningkatnya kemampuan berpikir tingkat tinggi siswa, yaitu hubungan masalah dengan kehidupan sehari-hari (real-world cases), diskusi kelas, dan kegiatan berbasis eksperimen.

Elektrokimia adalah salah satu topik dalam pelajaran kimia di SMA dan MA dengan Kompetensi Dasar pada domain C5, yang tergolong kemampuan berpikir tingkat tinggi menurut Bloom. Kompetensi dasar yang dituntut untuk dikuasai oleh siswa pada materi elektrokimia adalah "mengevaluasi gejala atau proses yang terjadi dalam sel elektrokimia dan sel elektrolisis." Domain evaluasi dapat diukur dengan beberapa indikator, di antaranya; 1) Memberikan penilaian terhadap solusi, gagasan, dan metodologi dengan menggunakan kriteria yang cocok atau standar yang ada untuk memastikan nilai efektivitas atau manfaatnya; 2) Membuat hipotesis, mengkritik dan melakukan pengujian; 3) Menerima atau menolak suatu pernyataan berdasarkan kriteria yang telah ditetapkan (Krathwohl, 2001).

Materi elektrokimia mencakup banyak konsep abstrak serta melibatkan representasi makroskopis, submikroskopis, dan simbolis. Hal ini cenderung menimbulkan kesulitan bagi siswa yang mempelajarinya (Garnet \& Treagust, 1992; Schmidt et al., 2007; Risa, 2015). Materi elektrokimia dipandang sulit tidak hanya oleh siswa tapi juga oleh guru yang mengajar materi tersebut (Ahtee, 2003; Haryani, 2014). Menurut Ogude \& Bradley (1996), materi elektrokimia bersifat kompleks. Para siswa banyak belajar dengan cara menghafal, misalnya dalam memecahkan persoalan kuantitatif dalam Hukum Faraday sehingga mengabaikan makna konseptual (Ozkaya et al.,2003). Pembelajaran dengan cara menghafal (rote learning) akan menyebabkan siswa kesulitan dalam memecahkan persoalan yang menuntut pemecahan nyata dalam kehidupan sehari-hari.

Data hasil survei terhadap siswa kelas XII SMA Trensains Tebuireng Jombang menunjukkan bahwa 57\% siswa memperoleh nilai di bawah KKM yang ditetapkan pada materi elektrokimia. Hal ini menunjukkan bahwa kemampuan siswa dalam "mengevaluasi" masih rendah. Rendahnya kemampuan berpikir tingkat tinggi siswa dapat bersumber dari faktor eksternal yaitu kurangnya dukungan perangkat pembelajaran yang digunakan (Lim, 2002).

Perangkat pembelajaran yang berkualitas harus memenuhi syarat validitas, kepraktisan, dan efektivitas (Nieveen, 1999). Perangkat pembelajaran dinyatakan valid jika perangkat tersebut sesuai dengan subjek ilmu dan semua komponen dalam perangkat tersebut saling berkaitan. Praktis dapat diartikan jika perangkat yang dikembangkan dapat dengan mudah digunakan oleh guru dan siswa dalam pembelajaran. Efektivitas perangkat pembelajaran dapat diukur dari meningkatnya hasil belajar siswa.

Pengunaan perangkat pembelajaran sebaiknya ditunjang dengan LKS agar menciptakan iklim siswa belajar secara aktif. Lembar kerja siswa LKS dapat meningkatkan sikap positif terhadap pembelajaran elektrokimia (Ural, 2016) sehingga minat dan hasil belajar siswa dapat meningkat. LKS memberikan kesempatan bagi siswa untuk secara mandiri mencapai indikator pembelajaran yang diharapkan. Para siswa dapat berlatih menentukan representasi yang terjadi pada sel elektrokimia dan sel elektrolisis dalam aspek simbolis, submikroskopis, dan makroskopis melalui LKS yang terintegrasi dengan kegiatan eksperimen. LKS yang dibutuhkan dalam menunjang kegiatan eksperimen pada materi elektrokimia belum tersedia di SMA Trensains tebuireng Jombang. Berdasarkan pemaparan tersebut maka tujuan penelitian adalah menghasilkan LKS yang valid, praktis, dan efektif untuk mendukung pembelajaran materi elektrokimia menggunakan model inkuiri terbimbing.

\section{METODE PENELITIAN}

Penelitian ini merupakan penelitian pengembangan yang mengembangkan Lembar Kerja Siswa SMA dengan model inkuiri terbimbing pada materi elektrokimia. Sumber data penelitian berasal dari 20 siswa pada pilot implementation yang dilaksanakan pada bulan September 2016 dan 49 siswa dari dua kelas sasaran pada final implementation yang dilaksanakan pada bulan Januari 2017.

Penelitian ini menggunakan pendekatan pre experiment design dengan rancangan penelitian One Group Pretest-Posttest. Pengembangan LKS pada penelitian ini menggunakan desain pengembangan ADDIE. Desain ini terdiri atas lima tahap, yaitu: (1) analyze (analisis kebutuhan, analisis siswa, analisis tugas, dan analisis konsep); (2) Design (merancang rumusan indikator dan tujuan pembelajaran, menentukan model pembelajaran, dan menyusun instrumen penilaian pembelajaran); (3) Develop (mengembangkan perangkat pembelajaran, validasi dan revisi perangkat pembelajaran); (4) Implement (pilot implementation dan 
final implementation); (5) Evaluate (evaluasi formatif dan evaluasi sumatif) yang diadaptasi dari Branch (2009).

Metode pengumpulan data yang digunakan adalah: (1) metode angket untuk memperoleh data validitas LKS;

(2) metode observasi untuk memperoleh data aktivitas siswa; (3) metode tes untuk memperoleh data hasil belajar siswa yang terdiri atas pretest dan posttest.

Instrumen penelitian yang digunakan adalah lembar validasi, lembar pengamatan aktivitas siswa, instrumen penilaian pembelajaran berbentuk pilihan ganda dua tingkat. Data yang diperoleh dianalisis secara deskriptif kuantitatif dan statistik inferensial.

Data hasil validasi LKS dianalisis secara deskriptif kuantitatif dengan mengkategorisasi skor rata-rata dalam interval 1-4 seperti ditunjukkan pada Tabel 1.

Tabel 1. Kategorisasi Hasil Validasi LKS

\begin{tabular}{|l|l|}
\hline Interval Skor & Kategori Penilaian \\
\hline $3,60 \leq$ skor $\leq 4,00$ & Sangat valid \\
\hline $2,60 \leq$ skor $<3,60$ & Valid \\
\hline $1,60 \leq$ skor $<2,60$ & Kurang valid \\
\hline $1,00 \leq$ skor $<1,60$ & Tidak valid \\
\hline
\end{tabular}

(Ratumanan \& Laurens, 2011)

Data hasil pengamatan aktivitas siswa dianalisis secara deskriptif kuantitatif dengan mengkategorisasi skor ratarata dalam interval $0 \%-100 \%$ seperti ditunjukkan pada Tabel 2.

Tabel 2. Kategorisasi Aktivitas Siswa

\begin{tabular}{|l|l|}
\hline Persentase Skor & Kategori \\
\hline $81 \%-100 \%$ & Sangat baik \\
\hline $61 \%-80 \%$ & Baik \\
\hline $41 \%-60 \%$ & Sedang \\
\hline $21 \%-40 \%$ & Kurang \\
\hline $0 \%-20 \%$ & Sangat kurang \\
\hline
\end{tabular}

(Riduwan, 2010)

Data pretest dan posttest siswa dianalisis secara statistik inferensial menggunakan uji-t satu pihak dengan rumusan hipotesis sebagai berikut.

$\mathrm{H}_{\mathrm{o}}$ : Nilai rata-rata hasil belajar siswa sama dengan nilai rata-rata pengetahuan awal siswa

$\mathrm{H}_{1}$ : Nilai rata-rata hasil belajar siswa lebih besar daripada nilai rata-rata pengetahuan awal siswa.

Daerah penerimaan Ho adalah $\mathrm{t}$ hitung $\leq \mathrm{t}$ tabel. Daerah penerimaan Ho adalah $\mathrm{t}$ hitung $>\mathrm{t}$ tabel. Taraf signifikansi $(\alpha)$ yang digunakan adalah 0,05 .

\section{HASIL DAN PEMBAHASAN}

A. Validitas Lembar Kerja Siswa

Validasi dilakukan oleh tiga orang expert yang meliputi validitas konstruk dn validitas isi. Hasil validasi dapat dirangkum dalam Tabel 3.
Tabel 3. Hasil Validasi LKS

\begin{tabular}{|l|l|l|l|}
\hline \multicolumn{2}{|c|}{ Aspek yang divalidasi } & $\begin{array}{c}\text { Skor } \\
\text { rata- } \\
\text { rata }\end{array}$ & K \\
\hline $\begin{array}{l}\text { Validitas } \\
\text { isi }\end{array}$ & $\begin{array}{l}\text { Relevansi dengan } \\
\text { argumen teoritis } \\
\text { mengenai model IT }\end{array}$ & 3,7 & SB \\
\cline { 2 - 4 } & $\begin{array}{l}\text { Relevansi dengan sintaks } \\
\text { model IT }\end{array}$ & 4,0 & SB \\
\cline { 2 - 4 } & $\begin{array}{l}\text { Relevansi dalam } \\
\text { pemenuhan hasil belajar } \\
\text { aspek pengetahuan }\end{array}$ & 4,0 & SB \\
\cline { 2 - 4 } & $\begin{array}{l}\text { Relevansi dengan kaidah } \\
\text { keilmuan }\end{array}$ & 3,7 & SB \\
\hline $\begin{array}{l}\text { Validitas } \\
\text { konstruk }\end{array}$ & Konstruksi fitur-fitur LKS & 3,84 & SB \\
\cline { 2 - 4 } & Syarat didaktis & 3,71 & SB \\
\cline { 2 - 4 } & Kebahasaan & 3,43 & B \\
\hline
\end{tabular}

Keterangan:

$\mathrm{K}$ : Kategori

SB: Sangat Baik

B : Baik

IT : Inkuiri Terbimbing

Penilaian terhadap validitas isi memperoleh nilai rata-rata 3,85 dengan kategori sangat valid. Tidak terdapat koreksi atau saran terhadap isi LKS sehingga isi LKS telah sangat valid dan dapat digunakan dalam pembelajaran.

Penilaian terhadap validitas konstruk LKS mendapat kriteria sangat valid dengan rata-rata 3,72. Terdapat beberapa saran yang diberikan oleh para expert di antaranya mengganti rumusan hipotesis, menyesuaikan fase LKS dengan sintaks inkuiri terbimbing, dan memperbaiki penulisan variabel eksperimen. Revisi telah dilakukan peneliti sesuai dengan saran dan koreksi dari validator.

Dampak dari LKS yang berkategori valid dan sangat valid adalah adalah LKS tersebut telah memadai untuk dapat diterapkan dengan praktis dan efektif mengatasi masalah yang menjadi latar belakang pengembangan LKS tersebut, yaitu memfasilitasi kegiatan pembelajaran inkuiri terbimbing yang sesuai dengan metode ilmiah. Sebelumnya belum tersedia LKS yang secara detail memaparkan aktivitas siswa dalam berproses seperti saintis untuk mendapatkan dan mengolah pengetahuan.

B. Kepraktisan Lembar Kerja Siswa

Kepraktisan LKS dianalisis berdasarkan hasil pengamatan aktivitas siswa. LKS dinyatakan praktis apabila aktivitas siswa dalam melaksanakan sintaks inkuiri terbimbing mencapai kategori minimal baik. Sintaks inkuiri terbimbing terdiri dari enam fase, yaitu: (1) merumuskan masalah berdasar fenomena ilmiah; (2) mengajukan hipotesis; (3) menyusun rencana praktikum dan mengumpullkan data; (4) menganalisis dan menginterpretasi hasil; 
mendiskusikan hasil dan menarik simpulan; (6) merefleksi pembelajaran dan mengembangkan konsep (Ong \& Borich, 2006).

Tabel 4. Hasil Pengamtan Akivitas Siswa

\begin{tabular}{|c|c|c|c|c|}
\hline \multirow[b]{2}{*}{ No. } & \multirow[b]{2}{*}{ Aspek } & \multicolumn{3}{|c|}{ Kelas Sasaran } \\
\hline & & $\begin{array}{c}\mathrm{K} 1 \\
(\%)\end{array}$ & $\begin{array}{l}\mathrm{K} 2 \\
(\%)\end{array}$ & $\begin{array}{l}\text { K3 } \\
(\%)\end{array}$ \\
\hline 1. & $\begin{array}{l}\text { Mengamati } \\
\text { demonstrasi guru. }\end{array}$ & 84 & 84 & 83 \\
\hline 2. & $\begin{array}{l}\text { Membaca } \\
\text { fenomena pada } \\
\text { LKS. }\end{array}$ & 84 & 86 & 82 \\
\hline 3. & $\begin{array}{l}\text { Merumuskan } \\
\text { masalah dalam } \\
\text { LKS. }\end{array}$ & 76 & 85 & 86 \\
\hline 4. & $\begin{array}{l}\text { Membaca bahan } \\
\text { ajar. }\end{array}$ & 87 & 85 & 86 \\
\hline 5. & $\begin{array}{l}\text { Menuliskan } \\
\text { konsep-konsep } \\
\text { relevan dalam } \\
\text { LKS. }\end{array}$ & 76 & 76 & 76 \\
\hline 6. & $\begin{array}{l}\text { Merumuskan } \\
\text { hipotesis dalam } \\
\text { LKS. }\end{array}$ & 74 & 82 & 85 \\
\hline 7. & $\begin{array}{l}\text { Menentukan } \\
\text { variabel-variabel } \\
\text { eksperimen. }\end{array}$ & 70 & 82 & 81 \\
\hline 8. & $\begin{array}{l}\text { Merancang } \\
\text { prosedur } \\
\text { eksperimen. }\end{array}$ & 74 & 82 & 82 \\
\hline 9. & $\begin{array}{l}\text { Melakukan } \\
\text { kegiatan } \\
\text { eksperimen. }\end{array}$ & 95 & 92 & 95 \\
\hline 10. & $\begin{array}{l}\text { Mencatat data } \\
\text { hasil eksperimen. }\end{array}$ & 85 & 84 & 87 \\
\hline 11. & $\begin{array}{l}\text { Menganalisis data } \\
\text { hasil eksperimen } \\
\text { melalui diskusi } \\
\text { dalam kelompok } \\
\text { masing-masing. }\end{array}$ & 81 & 82 & 84 \\
\hline 12. & $\begin{array}{l}\text { Membuat } \\
\text { simpulan hasil } \\
\text { kegiatan } \\
\text { eksperimen. }\end{array}$ & 80 & 83 & 81 \\
\hline 13. & $\begin{array}{l}\text { Mempresentasi- } \\
\text { kan hasil } \\
\text { kegiatan } \\
\text { eksperimen. }\end{array}$ & 73 & 86 & 84 \\
\hline 14. & $\begin{array}{l}\text { Melakukan } \\
\text { refleksi. }\end{array}$ & 72 & 82 & 82 \\
\hline 15. & $\begin{array}{l}\text { Melakukan } \\
\text { pengembangan } \\
\text { konsep. }\end{array}$ & 73 & 77 & 74 \\
\hline $\begin{array}{l}\text { Keter } \\
\text { K-1 } \\
\text { K-2 } \\
\text { K-3 }\end{array}$ & $\begin{array}{l}\text { : Kelas Pilot Im } \\
\text { : Kelas Sasaran } \\
\text { : Kelas Sasaran }\end{array}$ & $\begin{array}{l}\text { menta } \\
\text { final in } \\
\text { final } i\end{array}$ & $\begin{array}{l}\text { menta } \\
\text { ementc }\end{array}$ & \\
\hline
\end{tabular}

Hasil pengamatan aktivitas siswa pada masingmasing kelas implementation menunjukkan bahwa LKS yang dikembangkan telah memberikan dukungan yang positif terhadap aktivitas siswa dalam melaksanakan model inkuiri terbimbing. Hal ini ditunjukkan dengan persentase minimal $\geq 60 \%$ pada pilot implementation dan persentase minimal $\geq$
$70 \%$ pada final implementation. Beberapa aktivitas menunjukkan perbedaan ketika diterapkan pada final implementation, yaitu merumuskan masalah, merumuskan hipotesis, mempresentasikan hasil, dan membuat simpulan yang memperoleh predikat ratarata SB (sangat baik). Aktivitas tersebut mendapat predikat rata-rata B (baik) pada pilot implementation. Hal ini dikarenakan peneliti melakukan beberapa intervensi terhadap LKS berdasarkan hasil evaluasi formatif dengan meninjau proses pilot implementation. Perubahan yang dilakukan yaitu memberikan petunjuk berupa kalimat panduan dalam membantu siswa menyusun prosedur eksperimen dan melengkapi LKS dengan ruang khusus yang berisi panduan dalam melakukan presentasi dan menyampaikan pendapat. Peneliti berargumen bahwa tidak semua siswa dapat mengomunikasikan pendapat secara lisan sehingga diperlukan ruang khusus pada LKS agar siswa dapat menuliskan pendapatnya. Hal ini sesuai dengan pendapat Kuhltau \& Todd (2008) bahwa siswa mempunyai cara yang berbeda dalam pembelajaran.

Pengajaran yang secara aktif melibatkan siswa dalam proses pembelajaran melalui penyelidikan ilmiah lebih meningkatkan pemahaman konseptual daripada strategi yang mengandalkan teknik pasif (Berge et al., 2003). Dukungan perangkat pembelajaran terhadap aktivitas siswa telah mencapai kategori minimal baik, yang dengan kata lain telah dapat diterapkan dengan mudah sesuai rencana dan dapat digunakan tidak hanya oleh pengembang perangkat tapi juga oleh guru, siswa, dan praktisi lain. Kelanjutan dari LKS yang praktis adalah diharapkan memberikan dampak terhadap meningkatnya kemampuan berpikir tingkat tinggi siswa melalui kegiatan inkuiri terbimbing.

C. Efektivitas Perangkat Pembelajaran

1. Deskripsi Hasil Belajar Siswa pada Pilot Implementation

Hasil belajar aspek pengetahuan yang diuji efektivitasnya berdasarkan pada kompetensi dasar pada kurikulum 2013 pada materi elektrokimia, yaitu "mengevaluasi gejala dan proses yang terjadi dalam sel elektrokimia dan sel elektrolisis." Indikator pembelajaran ditetapkan berdasarkan domain C-5 taksonomi Bloom, yaitu "mengevaluasi" yang menurut Bloom diklasifikasikan ke dalam kemampuan berpikir tingkat tinggi. Indikator yang dipilih menggunakan kata kerja memprediksi (predict), menyusun (construct), menghubungkan (relate), mempertimbangkan (estimate), dan mengevaluasi (evaluate) yang disesuaikan dengan level C-5 (Kemp \& Morrison, 1994). 
Soal tes hasil belajar siswa dikembangkan dalam bentuk pilihan ganda dua tingkat untuk menguji indikator-indikator pembelajaran agar dapat mencapai kompetensi dasar yang termasuk kategori berpikir tingkat tinggi. Soal pilihan ganda dua tingkat dapat digunakan untuk mengukur kemampuan siswa dalam berpikir tingkat tinggi. Hal ini karena soal pilihan ganda dua tingkat menyediakan dua tingkat soal, tingkat pertama (first tier) berupa pilihan jawaban dan tingkat kedua (second tier) berupa pilihan alasan yang mendasari jawaban tersebut (Shidiq, 2014).

Tabel 5. Persentase Jawaban "Benar" Siswa pada Pilot Implementation

\begin{tabular}{|c|c|c|c|c|c|c|}
\hline \multirow[t]{2}{*}{ No } & \multirow{2}{*}{$\begin{array}{c}\text { Indikator } \\
\text { pembelajaran }\end{array}$} & \multirow{2}{*}{$\begin{array}{l}\text { No } \\
\text { soal }\end{array}$} & \multicolumn{2}{|c|}{$\begin{array}{c}\text { First tier } \\
(\%)\end{array}$} & \multicolumn{2}{|c|}{$\begin{array}{c}\text { Second tier } \\
(\%)\end{array}$} \\
\hline & & & Pre & Post & Pre & Post \\
\hline \multirow[t]{3}{*}{1} & \multirow{3}{*}{$\begin{array}{l}\text { Memprediksi } \\
\text { kespontanan } \\
\text { reaksi } \\
\text { elektrokimia } \\
\text { berdasarkan } \\
\text { data potensial } \\
\text { reduksi/oksidas } \\
\text { i dan deret } \\
\text { volta. }\end{array}$} & 1 & 50 & 85 & 10 & 80 \\
\hline & & 2 & 60 & 90 & 15 & 80 \\
\hline & & 3 & 30 & 75 & 25 & 80 \\
\hline \multicolumn{3}{|c|}{ Rata-rata } & 46,7 & 83,3 & 16,7 & 80 \\
\hline \multirow[t]{3}{*}{2} & \multirow{3}{*}{$\begin{array}{l}\text { Menyusun } \\
\text { rangkaian sel } \\
\text { volta } \\
\text { menggunakan } \\
\text { berbagai } \\
\text { kombinasi } \\
\text { elektrode } \\
\text { logam. }\end{array}$} & 4 & 50 & 95 & 30 & 85 \\
\hline & & 5 & 50 & 80 & 30 & 55 \\
\hline & & 6 & 35 & 50 & 15 & 100 \\
\hline \multicolumn{3}{|c|}{ Rata-rata } & 45 & 75 & 25 & 80 \\
\hline \multirow[t]{3}{*}{3} & \multirow{3}{*}{$\begin{array}{l}\text { Mengevaluasi } \\
\text { proses yang } \\
\text { terjadi dalam } \\
\text { sel volta. }\end{array}$} & 7 & 35 & 65 & 15 & 40 \\
\hline & & 8 & 45 & 55 & 10 & 40 \\
\hline & & 9 & 30 & 100 & 20 & 80 \\
\hline \multicolumn{3}{|c|}{ Rata-rata } & 36,7 & 73,3 & 15 & 53,3 \\
\hline \multirow[t]{3}{*}{4} & \multirow[b]{3}{*}{$\begin{array}{l}\text { Mempertimban } \\
\text { gkan produk } \\
\text { hasil } \\
\text { elektrolisis di } \\
\text { katode dan } \\
\text { anode } \\
\text { berdasarkan } \\
\text { data potensial } \\
\text { elektrode, } \\
\text { konsentrasi, } \\
\text { dan jenis } \\
\text { elektrode. }\end{array}$} & 10 & 50 & 95 & 55 & 65 \\
\hline & & 11 & 50 & 100 & 60 & 80 \\
\hline & & 12 & 65 & 85 & 40 & 80 \\
\hline \multicolumn{3}{|c|}{ Rata-rata } & 55 & 93,3 & 51,7 & 93,3 \\
\hline \multirow[t]{3}{*}{5} & \multirow{3}{*}{$\begin{array}{l}\text { Menghubungka } \\
\mathrm{n} \text { aspek } \\
\text { kuantitatif } \\
\text { reaksi } \\
\text { elektrolisis } \\
\text { dengan hukum } \\
\text { Faraday. }\end{array}$} & 13 & 50 & 100 & 55 & 90 \\
\hline & & 14 & 35 & 95 & 30 & 70 \\
\hline & & 15 & 65 & 95 & 5 & 85 \\
\hline & ta-rata & & 50 & 96,7 & 30 & 81,7 \\
\hline
\end{tabular}

\begin{tabular}{|c|l|c|c|c|c|c|}
\hline No & \multicolumn{1}{|c|}{$\begin{array}{l}\text { Indikator } \\
\text { pembelajaran }\end{array}$} & $\begin{array}{l}\text { No } \\
\text { soal }\end{array}$ & \multicolumn{2}{|c|}{$\begin{array}{c}\text { First tier } \\
(\%)\end{array}$} & \multicolumn{2}{|c|}{$\begin{array}{c}\text { Second tier } \\
(\%)\end{array}$} \\
\hline 6 & $\begin{array}{l}\text { Mengevaluasi } \\
\text { gejala dan } \\
\text { proses yang } \\
\text { terjadi dalam } \\
\text { sel elektrolisis. }\end{array}$ & 16 & 40 & 95 & 60 & 80 \\
\cline { 2 - 7 } & 17 & 55 & 85 & 15 & 80 \\
\cline { 2 - 7 } & 18 & 50 & 85 & 50 & 60 \\
\hline \multicolumn{2}{|l|}{ Rata-rata } & 48,3 & 88,3 & 41,7 & 73,3 \\
\hline
\end{tabular}

Tabel 5 menunjukkan bahwa siswa lebih dapat menjawab pertanyaan pada first tier daripada menjawab pada second tier. Hal ini menunjukkan bahwa siswa masih kesulitan menemukan alasan dari jawaban yang dipilih sehingga dapat dinyatakan bahwa kemampuan berpikir siswa masih rendah. Rendahnya kemampuan berpikir siswa dapat diartikan bahwa hasil belajar siswa belum memadai seperti yang diharapkan.

Setiap nomor pada instrumen penialian pilihan ganda dua tingkat merupakan penjabaran dari kemampuan berpikir tingkat tinggi pada level C-5 yang diadaptasi dari Kemp \& Morrison (1999). Berdasarkan Tabel 4 dapat dianalisis bahwa hampir seluruh indikator jawaban "benar" siswa dalam soal pretest pada masing-masing tingkat berada pada persentase di bawah 60\%. Persentase jawaban "benar" siswa pada pretest terendah adalah indikator nomor 4, yaitu "mengevaluasi gejala dan proses yang terjadi dalam sel volta." Persentase jawaban "benar" tertinggi adalah indikator nomor 5, yaitu pada indikator "mempertimbangkan produk hasil elektrolisis berdasarkan data potensial elektrode, konsentrasi, dan jenis elektrode."

Hasil posttest siswa pada pilot implementation menunjukkan bahwa hampir seluruh indikator jawaban "benar" siswa pada masing-masing tingkat berada pada persentase di atas $73 \%$. Hal ini menunjukkan peningkatan daripada hasil pretest sehingga dapat dinyatakan bahwa kemampuan berpikir tingkat tinggi siswa mengalami peningkatan. Persentase jawaban "benar" siswa terendah adalah indikator nomor 3, yaitu“"mengevaluasi gejala dan proses yang terjadi dalam sel volta." Persentase jawaban "benar" tertinggi adalah indikator nomor 5, yaitu "menghubungkan aspek kuantitatif reaksi elektrolisis dengan hukum faraday."

2. Deskripsi Hasil Belajar Siswa pada Kelas Sasaran I (Final Implementation)

Tabel 6. Deskripsi Persentase Jawaban "Benar" Siswa pada Kelas Sasaran I

\begin{tabular}{|c|c|c|c|l|c|l|}
\hline \multirow{2}{*}{ No } & \multirow{2}{*}{$\begin{array}{c}\text { Indikator } \\
\text { pembelajaran }\end{array}$} & \multirow{2}{*}{$\begin{array}{l}\text { No } \\
\text { soal }\end{array}$} & \multicolumn{2}{|c|}{$\begin{array}{c}\text { First tier } \\
(\boldsymbol{\%})\end{array}$} & \multicolumn{2}{|c|}{$\begin{array}{c}\text { Second tier } \\
(\%)\end{array}$} \\
\cline { 4 - 7 } & & & Pre & Post & Pre & Post \\
\hline 1 & Memprediksi & 1 & 40 & 85 & 10 & 80 \\
\hline
\end{tabular}




\begin{tabular}{|c|c|c|c|c|c|c|}
\hline \multirow[t]{3}{*}{ No } & \multirow{3}{*}{$\begin{array}{l}\quad \text { Indikator } \\
\text { pembelajaran } \\
\text { kespontanan } \\
\text { reaksi } \\
\text { elektrokimia } \\
\text { berdasarkan data } \\
\text { potensial } \\
\text { reduksi/oksidasi } \\
\text { dan deret volta. }\end{array}$} & \multirow{2}{*}{\begin{tabular}{|l|} 
No \\
soal
\end{tabular}} & \multicolumn{2}{|c|}{$\begin{array}{c}\text { First tier } \\
(\%)\end{array}$} & \multicolumn{2}{|c|}{$\begin{array}{c}\text { Second tier } \\
(\%)\end{array}$} \\
\hline & & & 60 & 90 & 25 & 90 \\
\hline & & 3 & 30 & 85 & 25 & 80 \\
\hline \multicolumn{3}{|c|}{ Rata-rata } & 43,3 & 86,7 & 20 & 85 \\
\hline \multirow[t]{3}{*}{2} & \multirow{3}{*}{$\begin{array}{l}\text { Menyusun } \\
\text { rangkaian sel } \\
\text { volta } \\
\text { menggunakan } \\
\text { berbagai } \\
\text { kombinasi } \\
\text { elektrode logam. }\end{array}$} & 4 & 50 & 95 & 30 & 85 \\
\hline & & 5 & 40 & 80 & 30 & 70 \\
\hline & & 6 & 35 & 70 & 20 & 100 \\
\hline \multicolumn{3}{|c|}{ Rata-rata } & 41,7 & 82 & 26,7 & 85 \\
\hline \multirow[t]{3}{*}{3} & \multirow{3}{*}{$\begin{array}{l}\text { Mengevaluasi } \\
\text { proses yang } \\
\text { terjadi dalam sel } \\
\text { volta. } \\
\end{array}$} & 7 & 30 & 85 & 15 & 70 \\
\hline & & 8 & 45 & 80 & 15 & 60 \\
\hline & & 9 & 30 & 100 & 20 & 80 \\
\hline \multicolumn{3}{|c|}{ Rata-rata } & 35 & 83,3 & 16,7 & 70 \\
\hline \multirow[t]{3}{*}{4} & \multirow{3}{*}{$\begin{array}{l}\text { Mempertimbangk } \\
\text { an produk hasil } \\
\text { elektrolisis di } \\
\text { katode dan anode } \\
\text { berdasarkan data } \\
\text { potensial } \\
\text { elektrode, } \\
\text { konsentrasi, dan } \\
\text { jenis elektrode. }\end{array}$} & 10 & 50 & 95 & 55 & 65 \\
\hline & & 11 & 55 & 100 & 60 & 80 \\
\hline & & 12 & 65 & 85 & 45 & 80 \\
\hline \multicolumn{3}{|c|}{ Rata-rata } & 58 & 93,3 & 53 & 75 \\
\hline \multirow[t]{3}{*}{5} & \multirow{3}{*}{$\begin{array}{l}\text { Menghubungkan } \\
\text { aspek kuantitatif } \\
\text { reaksi elektrolisis } \\
\text { dengan hukum } \\
\text { Faraday. }\end{array}$} & 13 & 50 & 100 & 55 & 90 \\
\hline & & 14 & 30 & 95 & 20 & 70 \\
\hline & & 15 & 65 & 95 & 5 & 75 \\
\hline & Rata-rata & & 48,3 & 94,5 & 26,7 & 78,3 \\
\hline \multirow[t]{3}{*}{6} & \multirow{3}{*}{$\begin{array}{l}\text { Mengevaluasi } \\
\text { gejala dan proses } \\
\text { yang terjadi dalam } \\
\text { sel elektrolisis. }\end{array}$} & 16 & 40 & 95 & 60 & 80 \\
\hline & & 17 & 55 & 90 & 15 & 80 \\
\hline & & 18 & 50 & 85 & 50 & 70 \\
\hline \multicolumn{3}{|c|}{ Rata-rata } & 48,3 & 90 & 41,7 & 76,7 \\
\hline
\end{tabular}

Berdasarkan Tabel 6 dapat dianalisis bahwa hampir seluruh indikator jawaban "benar" pada pretest siswa pada masing-masing tingkat berada pada persentase di bawah $60 \%$. Persentase jawaban "benar" siswa terendah adalah indikator nomor 3, yaitu "mengevaluasi gejala dan proses yang terjadi dalam sel volta." Persentase jawaban "benar" tertinggi adalah indikator nomor 4 yaitu "mempertimbangkan produk hasil elektrolisis berdasarkan data potensial elektrode, konsentrasi, dan jenis elektrode."

Hasil posttest siswa pada kelas sasaran I menunjukkan bahwa hampir seluruh indikator jawaban "benar" siswa pada masing-masing tingkat berada pada persentase di atas $73 \%$. Persentase jawaban "benar" siswa terendah adalah indikator nomor 3. Persentase jawaban "benar" tertinggi adalah indikator nomor 5 "menghubungkan aspek kuantitatif reaksi elektrolisis dengan hukum faraday."

3. Deskripsi Hasil Belajar Siswa pada Kelas Sasaran II (final implementation)

Tabel 7. Deskripsi Persentase Jawaban “Benar” Siswa pada Kelas Sasaran II

\begin{tabular}{|c|c|c|c|c|c|c|}
\hline \multirow[t]{2}{*}{ No } & \multirow{2}{*}{$\begin{array}{c}\text { Indikator } \\
\text { pembelajaran }\end{array}$} & \multirow{2}{*}{$\begin{array}{l}\text { No } \\
\text { soal }\end{array}$} & \multicolumn{2}{|c|}{$\begin{array}{c}\text { First tier } \\
(\%)\end{array}$} & \multicolumn{2}{|c|}{$\begin{array}{l}\text { Second tier } \\
(\%)\end{array}$} \\
\hline & & & Pre & Post & Pre & Post \\
\hline \multirow[t]{3}{*}{1} & \multirow{3}{*}{$\begin{array}{l}\text { Memprediksi } \\
\text { kespontanan } \\
\text { reaksi } \\
\text { elektrokimia } \\
\text { berdasarkan } \\
\text { data potensial } \\
\text { reduksi/oksidasi } \\
\text { dan deret volta. }\end{array}$} & 1 & 40 & 85 & 10 & 80 \\
\hline & & 2 & 60 & 90 & 25 & 90 \\
\hline & & 3 & 30 & 85 & 25 & 80 \\
\hline \multicolumn{3}{|c|}{ Rata-rata } & 43,3 & 86,7 & 20 & 85 \\
\hline \multirow[t]{3}{*}{2} & \multirow{3}{*}{$\begin{array}{l}\text { Menyusun } \\
\text { rangkaian sel } \\
\text { volta } \\
\text { menggunakan } \\
\text { berbagai } \\
\text { kombinasi } \\
\text { elektrode logam. }\end{array}$} & 4 & 50 & 95 & 30 & 85 \\
\hline & & 5 & 40 & 80 & 30 & 70 \\
\hline & & 6 & 35 & 75 & 20 & 90 \\
\hline \multicolumn{3}{|c|}{ Rata-rata } & 41,7 & 83 & 26,7 & 80 \\
\hline \multirow[t]{3}{*}{3} & \multirow{3}{*}{\begin{tabular}{|l} 
Mengevaluasi \\
proses yang \\
terjadi dalam sel \\
volta.
\end{tabular}} & 7 & 30 & 85 & 15 & 70 \\
\hline & & 8 & 45 & 80 & 15 & 60 \\
\hline & & 9 & 35 & 90 & 15 & 80 \\
\hline \multicolumn{3}{|c|}{ Rata-rata } & 40 & 85 & 15 & 70 \\
\hline \multirow[t]{3}{*}{4} & \multirow{3}{*}{$\begin{array}{l}\text { Mempertimbang } \\
\text { kan produk hasil } \\
\text { elektrolisis di } \\
\text { katode dan } \\
\text { anode } \\
\text { berdasarkan data } \\
\text { potensial } \\
\text { elektrode, } \\
\text { konsentrasi, danj } \\
\text { jenis elektrode. }\end{array}$} & 10 & 50 & 95 & 55 & 65 \\
\hline & & 11 & 60 & 100 & 60 & 80 \\
\hline & & 12 & 65 & 85 & 45 & 80 \\
\hline \multicolumn{3}{|c|}{ Rata-rata } & 50 & 93,3 & 50 & 75 \\
\hline \multirow[t]{3}{*}{5} & \multirow{3}{*}{$\begin{array}{l}\text { Menghubungkan } \\
\text { aspek kuantitatif } \\
\text { reaksi } \\
\text { elektrolisis } \\
\text { dengan hukum } \\
\text { Faraday. }\end{array}$} & 13 & 50 & 100 & 55 & 90 \\
\hline & & 14 & 30 & 90 & 20 & 70 \\
\hline & & 15 & 65 & 95 & 5 & 80 \\
\hline \multicolumn{3}{|c|}{ Rata-rata } & 48,3 & 94,7 & 26,7 & 80 \\
\hline \multirow[t]{3}{*}{6} & \multirow{3}{*}{$\begin{array}{l}\text { Mengevaluasi } \\
\text { gejala dan proses } \\
\text { yang terjadi } \\
\text { dalam sel } \\
\text { elektrolisis. }\end{array}$} & 16 & 40 & 95 & 60 & 80 \\
\hline & & 17 & 55 & 90 & 15 & 80 \\
\hline & & 18 & 50 & 85 & 50 & 70 \\
\hline \multicolumn{3}{|c|}{ Rata-rata } & 48,3 & 90 & 41,7 & 76,7 \\
\hline
\end{tabular}

Hasil pretest di kelas sasaran II menunjukkan bahwa persentase jawaban "benar" siswa terendah adalah pada indikator nomor 3, yaitu "mengevaluasi gejala dan proses 
yang terjadi dalam sel volta.” Hal ini sama dengan pretest pada pilot implementation dan kelas sasaran I.

Hasil posttest di kelas sasaran II menunjukkan bahwa persentase jawaban "benar" siswa terendah adalah sebesar $85 \%$ pada tingkat pertama dan $70 \%$ pada tingkat kedua yang merupakan indikator nomor 3, yaitu "mengevaluasi gejala dan proses yang terjadi dalam sel volta." Persentase jawaban "benar" tertinggi adalah sebesar $94,7 \%$ pada tingkat pertama dan $80 \%$ pada tingkat kedua yang merupakan indikator nomor 5 yaitu "menghubungkan aspek kuantitatif elektrolisis dengan hukum Faraday."

Siswa menunjukkan pemahaman yang sangat baik dalam indikator memprediksi kespontanan reaksi dan menghubungkan aspek kuantitatif elektrolisis dengan hukum faraday pada masing-masing kelas. Hal ini ditunjukkan dengan persentase jawaban "benar" siswa pada masing-masing tier berada di atas $80 \%$ pada masingmasing kelas implementation. Kemampuan siswa dalam indikator mengevaluasi gejala atau proses yang terjadi dalam sel volta pada tier kedua sebesar $78 \%$ di kelas sasaran I dan 75\% di kelas sasaran II. Persentase ini lebih tinggi daripada pilot implementation yang hanya sebesar $53,3 \%$. Peneliti berargumen diperlukan latihan soal yang lebih memadai pada LKS sehingga pada fitur "pengembangan" dalam LKS, perbaikan dilakukan dengan memberikan latihan soal yang relevan dengan indikator dan sesuai dengan kegiatan dalam LKS. Latihan soal yang memadai akan berdampak terhadap kemudahan siswa menguasai indikator pembelajaran pembelajaran yang diharapkan (Dahar, 2011).

Keberhasilan model pembelajaran inkuiri terbimbing dalam meningkatkan hasil belajar siswa tidak terlepas dari fase-fasenya yang telah diorganisasikan dengan baik, yang didukung oleh aktivitas siswa dengan kategori sangat baik. Hasil ini mendukung penelitian terdahulu yang relevan, di antaranya penelitian Nugraha (2013) yang mengemukakan bahwa terjadi peningkatan pemahaman konsep mahasiswa setelah diterapkan pembelajaran aktif berbasis inkuiri terbimbing. Mahasiswa termotivasi untuk berpartisipasi aktif dalam pembelajaran yang telah didesain dengan materi ajar kontekstual dan berguna dalam kehidupan. Bilgin (2009) mengemukakan bahwa pembelajaran pembelajaran menggunakan inkuiri secara signifikan membuat siswa mencapai hasil belajar (achievement) yang lebih baik dan menghasilkan sikap positif terhadap materi elektrokimia.

Uji signifikansi diperlukan untuk mengetahui apakah peningkatan kemampuan berpikir siswa pada masingmasing kelas implementation terjadi secara signifikan. Hasil analisis menggunakan uji-t dapat dilihat pada Tabel 8. Tabel tersebut menunjukkan bahwa terjadi peningkatan kemampuan berpikir tingkat tinggi secara signifikan pada masing-masing kelas implementation. Hasil ini sesuai dengan penelititan Madhuri et al. (2012) yang menunjukkan bahwa keterampilan berpikir tingkat tinggi dapat dilatihkan dengan pembelajaran berbasis pendekatan inkuiri daripada pembelajaran konvensional.

Tabel 8. Hasil Uji-t Dua Sampel Berpasangan (Paired Samples t-Test) Nilai Pretest dan Posttest

\begin{tabular}{|c|c|c|c|c|}
\hline Kelas & $\mathbf{t}$ tabel & $t_{\text {hitung }}$ & $\begin{array}{l}\text { Kesim- } \\
\text { pulan }\end{array}$ & Pernyataan \\
\hline $\begin{array}{c}\text { Pilot } \\
\text { imple- } \\
\text { menta- } \\
\text { tion }\end{array}$ & $\begin{array}{l}1,729 \\
(\alpha= \\
0,05 ; \\
d k= \\
24)\end{array}$ & 40,41 & $\begin{array}{l}\mathrm{H}_{\mathrm{o}} \\
\text { ditolak, } \\
\mathrm{H}_{1} \\
\text { diterima }\end{array}$ & $\begin{array}{l}\mu_{2}>\mu_{1} \text {. Nilai } \\
\text { rata-rata } \\
\text { Posttest } \text { secara } \\
\text { signifikan } \\
\text { meningkat/lebih } \\
\text { besar daripada } \\
\text { nilai rata-rata } \\
\text { Pretest pada } \\
\text { pilot } \\
\text { implementation }\end{array}$ \\
\hline $\begin{array}{c}\text { Kelas } \\
\text { Sasaran } \\
\text { I }\end{array}$ & $\begin{array}{l}1,708 \\
(\alpha= \\
0,05 ; \\
d k= \\
23)\end{array}$ & 14,8 & $\begin{array}{l}\mathrm{H}_{\mathrm{o}} \\
\text { ditolak, } \\
\mathrm{H}_{1} \\
\text { diterima }\end{array}$ & $\begin{array}{l}\mu_{2}>\mu_{1} \text {. Nilai } \\
\text { rata-rata } \\
\text { Posttest } \text { secara } \\
\text { signifikan } \\
\text { meningkat/lebih } \\
\text { besar daripada } \\
\text { nilai rata-rata } \\
\text { Pretest di kelas } \\
\text { sasaran I } \\
\end{array}$ \\
\hline $\begin{array}{c}\text { Kelas } \\
\text { Sasaran } \\
\text { II }\end{array}$ & $\begin{array}{l}1,708 \\
(\alpha= \\
0,05 ; \\
d k= \\
24)\end{array}$ & 17,7 & $\begin{array}{l}\mathrm{H}_{\mathrm{o}} \\
\text { ditolak, } \\
\mathrm{H}_{1} \\
\text { diterima }\end{array}$ & $\begin{array}{l}\mu_{2}>\mu_{1} \text { Nilai } \\
\text { rata-rata } \\
\text { Posttest secara } \\
\text { signifikan } \\
\text { meningkat/lebih } \\
\text { besar daripada } \\
\text { nilai rata-rata } \\
\text { Pretest di kelas } \\
\text { sasaran II }\end{array}$ \\
\hline
\end{tabular}

\section{PENUTUP}

\section{A. Simpulan}

Berdasarkan hasil penelitian yang telah dilakukan, maka dapat disimpulkan bahwa Lembar Kerja Siswa model inkuiri terbimbing pada materi elektrokimia telah valid, praktis, dan efektif.

\section{B. Saran}

Lembar Kerja Siswa perlu disempurnakan dengan memberikan petunjuk alokasi waktu agar siswa dapat memperkirakan kisaran waktu mengerjakan setiap langkah kegiatan.

\section{DAFTAR PUSTAKA}

Anderson, L.W. \& Krathwohl, D. R. (2001). A Taxonomy for Learning, Teaching, and Assessing : A Revision of Bloom's Taxonomy of Educational Objectives. Longman: New York.

Ahtee, M., Asunta. T., \& Palm, H. (2002) Student Teachers' Problems In Teaching 'Electrolysis'with A Key Demonstration. 
Chemistry Education: Research and Practice in Europe. 3(3), 317-326.

Berg, C. A. R., Bergendahl, V. C. B., \& Lundberg, B. K. S. (2003). Benefiting from an open-ended experiment? A comparison of attitudes to, and outcomes of, an expository versus an open-inquiry version of the same experiment. International Journal of Science Education. 25(3), 112-121.

Bilgin, I. (2009). The effects of guided inquiry instruction incorporating a cooperative learning approach on university students' achievement of acid and bases concepts and attitude toward guided inquiry instruction. Academic Journals of Scientific Researh and Essay. 4(10),1038-1046.

Branch, R. M. (2009). Instructional design: ADDIE approach. New York: Springer Science \& Business Media.

Dahar, R. W. (2011). Teori-teori belajar \& pembelajaran. Jakarta: Erlangga.

Garnett, P.J. \& Treagust, D. F. (1992). Conceptual difficulties experienced by senior high school students of electrochemistry: Electric circuits and oxidation-reduction equations. Journal of Research in Science Teaching, 29(2), 121-142.

Haryani, Sri. (2014). Identifikasi Materi Kimia SMA Sulit Menurut Pandangan Guru dan Calon Guru Kimia. Seminar Nasional Kimia dan Pendidikan Kimia VI, "Pemantapan Riset Kimia dan Asesmen dalam pembelajaran berbasiss Pendekatan Saintifik", Surakarta.

Kemp, J.E., G.R. Morrison, \& S.M. Ross. (1994). Designing Effective Instruction. New York: Macmillan College Publishing Company.

Kuhlthau, C.C. \& Todd, R. J. (2008). Guided inquiry: A framework for learning through school libraries in 21st century schools. Newark NJ: Rutgers University.

Lim, D. H., \& Johnson, S. (2002). Trainee Perceptions of factors that influence learning transfer. International Journal of Training and Development, 6 (1), 36-48.

McDonnel. (2013). The Effects of Guided Inquiry on Understanding High School Chemistry. Montana State University.

Millar, R., Osborne, J., \& Nott, M. (1998). Science Education fot the Future. [Report Descriptive]. School Science Review, 80 (291), 19-24

Miri, B., David, B.C., \& Uri, Z. (2007). Purposely teaching for the promotion of higher order thinking skills: A case of critical thinking. Research in Science Education, 37(4), 353-369.

Nieveen, N. (1999). Prototyping to Reach Product Quality. Netherlands: Springer.

Nugraha, M.G., \& Aviyanti, L. (2014, Juni). Profil Hasil Belajar Mahasiswa International Program on Science Education (IPSE)" dalam Matakuliah "Science in Daily Life" Melalui Implementasi Pembelajaran Aktif Berbasis Inkuiri. Seminar Nasional Inovasi Pendidikan, Institut Teknologi Bandung

Ogude, A.N., \& Bradley, J.D. (1996). Electrode processes and aspects relating to cell emf, current, and cell components in operating electrochemical cells. Journal of Chemical Education, 73(12), 1145-1149.

Ong, A \& Borich. (2006). Teaching Strategies that Promote Thinking: Models and Curriculum Approaches (First Edition). London: McGrawHill Education.

Ozkaya, R.A., Uce, M., \& Sahin, M. (2003). Prospective teachers' conceptual understanding of electrochemistry. The Royal Society of Chemistry. 7(1), 1-8.

Poulson, T. (2010). Introduction to Chemistry. New York: Amazon Company

Risa, H. (2015). Miskonsepsi pada Materi Elektrokimia Ditinjau dari Kemampuan Berpikir Ilmiah Siswa. Jurnal Pendidikan Kimia. 4(3), 79-84.

Ratumanan, G. T., \& Laurens.(2011). Evaluasi hasil belajar pada tingkat satuan pendidikan. Surabaya: Universitas Negeri Surabaya Press.

Riduwan.(2010). Skala pengukuran variabel-variabel penelitian. Bandung: Alfabeta.

Schmidt, H.J., A. Marohn \& A.G. Harisson, 2007. Factors that prevent learning in electrochemistry. Journal of Science and Educational Technology. 44, 258-283. DOI: 10.1002/tea.20118.

Shidiq, A. S., Masykuri, M., \& Susanti, E. (2014). Pengembangan instrumen penilaian two-tier multiple-choice untuk mengukur keterampilan berpikir tingkat tinggi (higher order thinking skills) pada materi kelarutan dan hasil kali kelarutan untuk siswa SMA/MA Kelas XI. Jurnal Pendidikan Kimia. 3(4), 83-92.

Ural, E. (2016). The effect of guided inquiry experiments on science education students' chemistry laboratory attitudes, anxiety, and achievement. Journal of Education and Training Studies, 4(4),217-227. 